\title{
A Responsabilidade Penal internacional dos indivíduos: Estudo do CASO DARFUR
}

\author{
The international criminal responsability of individuals: \\ DARFUR case
}

Laís Alves Camargos

Especialista em Direito Público pela Faculdade Milton Campos e em Direito Processual Civil pelo Instituto para o Direito Democrático (IDDE). Email: laisalves8@ gmail.com

RECEBIDO EM: 12.09.2012

APROVADO EM: 15.12.2012

\section{RESUMO}

Essa pesquisa possui como objetivo a demonstração da posição ativa que os indivíduos ocupam frente à normativa penal internacional, além de definir se é possível responsabilizar perante o TPI um cidadão de um país que não seja signatário do Estatuto de Roma, tendo como base o caso de DARFUR no Sudão. Para tanto foram analisados princípios, como da igualdade, da não discriminação, da legalidade internacional, do juiz natural e respeito aos direitos humanos, buscando assim, através da vertente sociológica e dogmática, definir o efeito da norma no meio social e no ordenamento jurídico, baseado em um caso concreto. Na presente situação, visa-se, portanto, deliberar acerca da responsabilização dos indivíduos no caso de DARFUR, onde os direitos humanos não estão sendo respeitados.

Palavras chave: Darfur (Sudão). Conflito armado. Crimes contra a humaniDAde. Crimes de agressão. Direitos humanos. Responsabilidade InTERnacional dos indivíduos. Tribunal Penal Internacional. 


\begin{abstract}
This research has the intention to demonstrate the active role that individuals currently occupy in the international criminal rules, and define whether it is possible to the ICC blame a citizen of a country that is not a signatory of the Rome Statute, based on the case Darfur in Sudan. Therefore, were analyzed principles such as equality, non discrimination, international legality and respect for human rights, searching through, from the sociological and dogmatic perspectives, define the effect of the standard in the social and legal system, based on a case. In this specific situation, the aim is to deliberate about the accountability of individuals upon DARFUR, where human rights are not being respected.
\end{abstract}

Keywords: DARFUR. Armed conflict. Crimes against humanity. Crimes of agGRESSION. HuMAN Rights. InTERNATIONAL RESPONSIBILITY OF INDIVIDUALS. INTERNATIONal Criminal Court.

SumáRIo: Introdução. 1. Histórico. 1.1 A responsabilidade individual. 1.2 O Direito Penal Internacional. 1.3 Desenvolvimento dos Direitos Humanos em relação aos crimes internacionais. 1.4 Os Tribunais Ad Hoc. 2. O TPI. 2.1 A soberania e a jurisdição do TPI. 2.2 Crime contra a humanidade. 2.3 Crime de guerra. 2.4 Crime de Genocídio. 2.5 Crime de agressão. 2.6 Princípios aplicados ao TPI. 3. DARFUR. 3.1 História do Sudão. 3.2. O conflito em DARFUR. Conclusão. Referências.

\title{
INTRODUÇ̃̃̃O
}

Trata-se de uma pesquisa que visa definir a possibilidade de responsabilizar internacionalmente cidadãos de países não signatários do Estatuto de Roma, mais especificamente em relação ao caso do Sudão. Esse Estatuto estabelece a averiguação e punição de responsáveis por crimes contra a humanidade, crimes de guerra, crimes de agressão e genocídio através do Tribunal Penal Internacional (TPI). Cabe ressaltar que essa corte tem como objetivo precípuo promover o Direito Internacional (DIP), mais especificamente o Direito Penal Internacional e tem competência para responsabilizar tão somente indivíduos, diferentemente da Corte Internacional de Justiça (CIJ), que possui jurisdição contenciosa em relação a Estados.

O caso do Sudão foi escolhido para essa pesquisa por ser um tema atual e também devido a extensão do sofrimento já causado pelo conflito na região, que corresponde a mais de 300 mil mortes, já tendo ultrapassado as fronteiras do Sudão, com milhares de refugiados escondidos no Chade e na a República Centro-Africana, 
onde continuam a ser perseguidos pelas milícias Janjaweed ${ }^{219}$.

Não obstante as já mencionadas mortes, a região do Oeste do Sudão conta com grupos armados que estão em conflito com o governo predominantemente árabe de Cartum, capital do país, devido ao abandono e descaso que ajudou a causar o baixo nível de desenvolvimento da região, o que, combinado com décadas de secas, desertificações e superpopulação, fomentou as disputas políticas na região. Em fevereiro de 2003, o grupo de rebeldes de DARFUR atacou postos do governo sudanês da região, o que acarretou no apoio aos Janjawid por parte do governo.

O promotor do TPI, o argentino Luis Moreno Ocampo, apresentou, em 2007, relatório sobre os crimes de guerra e contra a humanidade cometidos em DARFUR, com a finalidade de que os juízes expedissem ordens de prisão. O Sudão então voltou a rejeitar a legitimidade do TPI, acusou o tribunal de tentar prejudicar a processo de paz e ainda desobrigou-se de enviar seus cidadãos para Haia, sede do Tribunal. Foi a primeira vez que uma organização internacional tentou montar um processo contra um Chefe de Estado ainda em exercício. Em março de 2009 o TPI emitiu mandado de prisão contra o Presidente, Omar al-Bashir ${ }^{220}$, que está sendo acusado de ter cometido crimes de genocídio, crimes contra a humanidade e crimes de guerra.

O TPI, que é um órgão preocupado com a justiça e não com a diplomacia, foi criado como um meio de solução de controvérsia com intuito de assegurar a paz. Anteriormente, a repressão dos crimes internacionais cabia tão somente aos Estados e as normas do DIP não se projetavam na esfera jurídica dos indivíduos. Hoje, no entanto, a maioria dos doutrinadores defende ser o individuo sujeito do Direito Internacional. Uma exceção a essa concepção é a constante na doutrina de Francisco Rezek, que menciona como sujeitos somente Estados e Organizações Internacionais.

O problema está no fato de que mesmo cometendo atrocidades, os agressores não estão sendo responsabilizados pelo Direito interno. Esse trabalho visa então definir, perante o DIP, como o TPI pode responsabilizar tais indivíduos, considerando que seu Estado não é signatário do Estatuto de Roma.

\section{HistóRICO}

\subsection{A Responsabilidade INDIVIDUAL}

Antigamente o homem somente existia como membro de um grupo ou clã

219 São Criminosos que se apresentam como árabes embora sejam em geral provenientes de tribos africanas nômades de fala árabe. Desde 2003, tiveram papel central no conflito de DARFUR, que opõe a população árabe muçulmana do Sudão aos muçulmanos não-árabes da região devido a questões de distribuição de terras e recursos.

220 Presidente do Sudão desde 30 de junho de 1989 quando tomou o poder mediante um golpe de Estado. 
e, portanto, não havia a dimensão da responsabilidade penal, que era unicamente coletiva. (SOUZA, 2005.)

Com o fim da segunda Grande Guerra e a criação de tribunais ad hoc, o indivíduo começou a ser responsabilizado por seus próprios atos frente à normativa internacional, bem como a ser titular de direitos e deveres. Naquela época surgiram os primeiros documentos sobre os direitos humanos, que influenciaram a nova concepção acerca dos indivíduos no plano internacional.

A responsabilidade penal do indivíduo foi tipificada pela primeira vez no artigo $6^{\circ}$ do Estatuto do Tribunal de Nuremberg ${ }^{221}$. De acordo com a última frase do mencionado dispositivo, líderes, organizadores, investigadores e cúmplices são responsáveis pelos atos praticados considerados mais danosos à humanidade. Desta forma não restaram dúvidas que, naquele momento, houve a positivação da responsabilidade subjetiva dos indivíduos. Neste diapasão, foi consagrado o princípio da responsabilidade penal internacional dos indivíduos.

Desde aquela época até os dias atuais, apesar das modificações que foram sendo introduzidas em relação à responsabilidade individual dos indivíduos, o desenvolvimento desse instituto ainda tem suas bases mais importantes no que foi definido pelos vencedores da Segunda Guerra Mundial por ocasião do Tribunal de Nuremberg.

Atualmente, contudo, novas terminologias e definições foram sendo adotadas em relação a essa matéria. De acordo com Kai Ambos e Fauzi Hassan, existem algumas regras básicas de responsabilidade individual ${ }^{222}$, quais sejam: além das três formas de autoria, que são a direta ou imediata, a co-autoria (forma autônoma de autoria) e autoria mediata (por meio de outra(s) pessoa(s), outras formas de participação. Em relação a este ultimo ponto, é importante salientar que pode ainda existir um comandante, um solicitador ou indutor e aquele que auxilia, mesmo que o faça apenas facilitando para que o crime aconteça.

Cabe destacar, portanto, a responsabilidade de comando que está codificada no artigo 28 do Estatuto de Roma, e diz respeito também às omissões, nas quais o superior pode ser punido por sua incapacidade de controlar seus subordinados ante o cometimento de atrocidades. (AMBOS; CHOUKR, 2000)

Um conceito relevante refere-se aos elementos subjetivos da responsabilidade criminal individual (mens rea); de acordo com o artigo 30 do Estatuto, há exigência de que os crimes de competência do TPI tenham sido praticados com dolo, ou seja, com conhecimento dos fatos bem como da ilicitude dos mesmos e vontade.

221 De acordo com a redação original em inglês da Carta de Nuremberg de 8 de agosto de 1945: "Leaders, organizers, instigators and accomplices participating in the formulation or execution of a common plan or conspiracy to commit any of the foregoing crimes are responsible for all acts performed by any persons in execution of such plan": ONU, CONSELHO DE SEGURANÇA, 1945.

222 Artigo 25 do Estatuto de Roma do Tribunal Penal Internacional. 
$\mathrm{O}$ artigo $8^{\circ}$ do Estatuto de Roma também deixou claro que agir por ordem do governo ou de um superior não exime ninguém da responsabilidade, o que reforça a concepção de que os indivíduos são passíveis de responsabilização no âmbito internacional. (MAZZUOLI, 2007)

Atualmente verifica-se que os indivíduos podem participar ativamente (reclamando direitos) ou passivamente (sendo reclamados) dos litígios internacionais, possuindo, o que reafirma a teoria de que possuem personalidade jurídica internacional. Não obstante, ainda nos dias de hoje podemos encontrar alguns autores, como Francisco Rezek, que negam este status aos indivíduos e se fundamentam no fato de que eles não se envolvem na produção de normas internacionais ou guardam relação direta com e imediata com este corpo de normas. (REZEK, 2008)

Pode-se então dizer que

A condição dos indivíduos como detentores de personalidade jurídica internacional é uma das mais notáveis conquistas do direito internacional público do século XX, lograda em decorrência do processo de desenvolvimento e solidificação do direito internacional dos Direitos Humanos. (MAZZUOLI, 2007, 343)

\subsection{O Direito Penal Internacional}

Ao mesmo tempo em que surgia a responsabilidade penal internacional do indivíduo, o direito penal internacional também passou a existir como uma nova disciplina. Tudo isso ocorreu, portanto, na mesma época em que as Nações Unidas e, consequentemente, os Tribunais $A d$ Hoc foram criados. Pode-se dizer então que por meio desse novo ramo do Direito Internacional, as pessoas passaram a ser individualmente responsáveis pelas infrações cometidas contra os direitos humanos. (SOUZA, 2005)

E, como bem elucida Fernanda Nepomuceno:

O Direito Internacional Penal, portanto, protege os bens supremos como a paz e a dignidade do ser humano, tanto em tempo de paz como de guerra; e as infrações por ela incriminadas seriam os únicos e autênticos "delitos internacionais", como por exemplo, os crimes contra a paz, os crimes contra a humanidade e os crimes de guerra. (SOUZA, 2005, p.12)

Segundo Celso D. de Albuquerque Mello,

[...] o direito internacional penal pode ser definido de uma maneira concisa 
como sendo 'o conjunto de regras jurídicas concernente às infrações internacionais que constituem violações do direito internacional'. (MELLO, 2004, p. 1009)

Mello considera que o Direito Penal Internacional tem elementos que o aproxima mais do direito penal do que do direito internacional. Isso porque os princípios básicos do direito penal devem obrigatoriamente ser observados pelo direito penal internacional. (MELLO, 2004)

\subsection{Desenvolvimento dos Direitos Humanos em relaÇão aos Crimes iN- TERNACIONAIS}

A luta pelos direitos humanos é antiga e repleta de acontecimentos históricos, como a Revolução Parlamentar Inglesa de 1689, a Independência dos Estados Unidos em 1778 e a Revolução Francesa de 1789, todavia, o ano de 1948 é considerado marco na proteção internacional dos direitos humanos, pois naquela ocasião se deu a proteção internacional sistematizada de tais direitos. Antes disso, sua proteção era muito restrita, sendo encontrada apenas em algumas legislações internas de alguns países como Inglaterra e França. (SOUZA, 2005)

Segundo Denis Alland, os DH apareceram, na maioria das vezes, em cartas de ideais, desprovida de sanções, como exemplo há a Declaração dos Direitos do Homem e do Cidadão de 1789, que foi um dos documentos que mais influenciou a Declaração Universal de 1948. Naquela, "se proclamava a liberdade e a igualdade nos direitos de todos os homens, reivindicava seus direitos naturais e imprescritíveis [...]" (SOUZA, 2005, pp. 5-6; ALLAND, 2000)

Com as revoluções, principalmente a francesa, teve início no ocidente, as reivindicações econômicas e sociais e, após a Primeira Grande Guerra, questões relativas à proteção internacional de minorias no plano interno de alguns Estados soberanos passaram a ser consideradas como dignas de proteção, como no caso da acolhida de refugiados de guerra. A partir de então, o processo de consolidação dos DH se completou após a segunda grande guerra. (SOUZA, 2005)

Com a assinatura da Carta das Nações Unidas em 1945, houve comprometimento dos países signatários em "promover e encorajar o respeito aos Direitos Humanos e liberdades fundamentais de todos, sem distinção de raça, sexo, língua ou religião." (SOUZA, 2005, p.9)

Na reunião da Assembléia Geral em dezembro de 1948, foi definida a Declaração Universal dos Direitos Humanos e, o que era uma mera declaração, em razão da importância de seu conteúdo, passou a ter valor normativo (devido ao processo costumeiro) e a ser considerada como inspiração para as nações. (SOUZA, 2005)

Hoje, existem inúmeras normas e tratados internacionais acerca da proteção dos DH que não dependem de qualquer condição, bastando a qualidade de ser 
humana para a pessoa poder fazer reivindicações. (MAZZUOLI, 2007)

Muito relevante destacar, portanto, alguns conceitos. Como é o significado de 'direitos do homem', que

é expressão de cunho mais naturalista [...] e conota a série de direitos naturais (ou ainda não positivados) aptos à proteção global do homem. São direitos que, em tese, ainda não se encontram nos textos constitucionais ou nos tratados internacionais de proteção dos direitos humanos [...]. (MAZZUOLI, 2007, pp. 671-672)

e ainda o significado de 'direitos fundamentais':

é a expressão que mais afeta à proteção constitucional dos direitos dos cidadãos. Ligam-se, assim, aos aspectos ou matizes constitucionais (internos) de proteção, no sentido de já se encontram positivados nas constituições contemporâneas. (MAZZUOLI, 2007, p. 672)

Assim, os Direitos Humanos “[...] são, por sua vez, direitos inscritos (positivados) em tratados ou em costumes internacionais, ou seja, são aqueles direitos que já ascenderam ao patamar do Direito Internacional Público". (MAZZUOLI, 2007, p. 672)

Cabe destacar algumas características dos $\mathrm{DH}$, como a universalidade, a essencialidade, a irrenunciabilidade, a inalienabilidade, a imprescritibilidade, sendo esta ultima considerada como uma das mais importantes, por significar que os direitos humanos não se esgotam com o passar do tempo, o que permite que sua reivindicação seja permanente, não havendo, portanto, prescrição. (MAZZUOLI, 2007, p. 675)

Existe também a teoria que determina a existência de gerações dos $\mathrm{DH}$, que se iniciam com a primeira geração, da liberdade, passam pela segunda, da igualdade, pela terceira, que é a fraternidade e a quarta geração de DH é resultante da globalização dos direitos fundamentais, como por exemplo, a democracia e o pluralismo. (MAZZUOLI, 2007)

Segundo Bonavides, as três primeiras gerações traduzem um processo cumulativo e qualitativo, sendo os direitos da primeira geração, portanto, os direitos civis e políticos, ou seja, direitos de resistência ou oposição perante o Estado, não havendo Constituição atual que não os reconheça. Os direitos da segunda geração dominaram o século XX e correspondem aos direitos sociais, culturais e econômicos, bem como os coletivos ou de coletividades. Já os da terceira geração surgiram quando a sociedade internacional se deparou com o mundo dividido em nações desenvolvidas e subdesenvolvidas, aparecendo assim a necessidade da fraternidade e solidariedade. (BONAVIDES, 2003, pp. 562-569) 
Por derradeiro, os direitos da quarta geração se traduzem a partir da intensa globalização e da universalidade das relações de convivência, sendo, portanto, a democracia, o direito à informação e ao pluralismo os mais relevantes. (BONAVIDES, 2003, p. 571)

Assim, importante se faz a transcrição do artigo 55 da Carta das Nações Unidas:

Com o fim de criar condições de estabilidade e bem-estar, necessárias às relações pacíficas e amistosas entre as Nações, baseadas no respeito do princípio da igualdade de direitos e da autodeterminação dos povos, as Nações Unidas promoverão:

A elevação dos níveis de vida, o pleno emprego e condições de progresso e desenvolvimento econômico e social;

A solução dos problemas internacionais econômicos, sociais, de saúde e conexos, bem como a cooperação internacional, de caráter cultural e educacional;

O respeito universal e efetivo dos direitos do homem e das liberdades fundamentais para todos, sem distinção de raça, sexo, língua ou religião.

\subsection{Os Tribunais $A D$ Hoc}

Os Tribunais $A d$ Hoc tiveram origem com o final da Segunda Guerra Mundial, diante de um cenário repleto de atrocidades e mortes. Na mesma época e em virtude de preocupações internacionais semelhantes àquelas que resultaram no surgimento da responsabilidade internacional dos indivíduos, iniciou-se em nível internacional a preocupação com a positivação dos direitos humanos, a partir da Declaração Universal dos Direitos Humanos de 1948.

Depois de duas Grandes Guerras Mundiais, a sociedade estava clamando por justiça, pelo fim das impunidades e por reparações pelas atrocidades cometidas pelos nazistas em relação aos judeus, homossexuais e ciganos em campos de concentração e extermínio. Nesse contexto, foi assinada a Carta das Nações Unidas em 1945, responsável pela criação da ONU, que determinou ser o Conselho de Segurança (CS) o principal órgão para questões de paz e segurança internacional, com poderes decisórios sobre tais assuntos.

O CS, desta maneira, por meio de resoluções, determinou a criação de Tribunais $A d H o c$, como os Tribunais de Nuremberg e Tóquio, cujas atividades estão encerradas. Depois de algumas décadas sem que houvesse a necessidade de sua instituição, novos tribunais, que ainda estão em funcionamento, foram designados pelo Conselho de Segurança: Ruanda, antiga Iugoslávia e Líbano. (SOUZA, 2005)

Contudo, a primeira iniciativa para responsabilizar internacionalmente os indivíduos através de um tribunal instituído especialmente para este fim, aconteceu 
em 1474 na Alemanha, pelo qual o Império Romano julgou e condenou Peter Von Hagenbach por violações às leis humanas e divinas. (CALETTI, 2002)

O Tribunal Militar de Nuremberg foi criado em agosto de 1945 na Inglaterra através do Acordo de Londres, com o objetivo de punir os criminoso de guerra das potencias européias do Eixo, formada por Alemanha, Itália e Japão principalmente. Todavia, só entrou em funcionamento em outubro do mesmo ano julgando $24 \mathrm{mem}$ bros do partido e do governo nazista e ainda 8 organizações acusadas de crimes de guerra. Ao final de 218 dias de audiências, todos os acusados se declararam inocentes e os veredictos correspondem a doze condenações à morte, nove à prisão e três absolvições.

Insta salientar que esse tribunal julgou, na maioria dos casos, médicos acusados de fazerem experiências em humanos, que foram também acusados de arquitetarem programas pró-eutanásia, além de induzirem a morte daqueles que acreditavam improdutivos para a vida.

Todavia, o Tribunal de Nuremberg recebeu algumas críticas pelo fato de acharem que os acusados deveriam ter sido julgados pelas leis de seus próprios países e não em julgamento fundamentado em uma ordem instituída após uma guerra. Outro ponto muito questionado foi o de que nenhum dos vencedores da guerra fora julgado. (CALETTI, 2002) Muito importante ressaltar ainda que o artigo $7^{\circ}$ do Acordo de Londres determinou que a atividade de Chefe de Estado exercida por um indivíduo não o isentava ou seria fonte de atenuação para imposição de sansões. (BAZELAIRE; CRETIN, 2004)

Acerca do funcionamento, o Tribunal era composto por quatro membros, ou seja, cada país aliado tinha um procurador titular e um suplente visando garantir uma punição justa e rápida aos criminosos nazistas, sendo que havia também um juiz de cada país. As penas eram determinadas pelo Tribunal desde que as considerasse justa e apropriada, cabendo inclusive pena de morte. (BAZELAIRE; CRETIN, 2004)

Esta corte possuía sede no Palácio de Justiça da cidade de Nuremberg situado na Further Strasse, na Alemanha. Na verdade, de acordo com artigo 22, Berlim era a sede permanente e Nuremberg o local onde os julgamentos ocorreriam.

O Tribunal de Nuremberg significou, um grande impulso à internacionalização dos direitos humanos e o artigo $6^{\circ}$ do Acordo de Londres ${ }^{223}$ tipificou os crimes de competência daquele tribunal, quais sejam crimes contra a paz, de guerra e contra a humanidade. (CALETTI, 2002; MAZZZUOLI, 2007)

O segundo Tribunal $A d$ Hoc originado em razão dos crimes cometidos na Segunda Guerra Mundial foi o Militar de Tóquio, também instituído para julgar crimes de guerra e contra a humanidade, seguiu os moldes do de Nuremberg e julgou 28 criminosos de guerra. (BAZELAIRE; CRETIN, 2004)

223 Artigo $6^{\circ}:[\ldots]$ Os atos a seguir, ou qualquer um deles, são os crimes submetidos à Jurisdição do tribunal e levaram a uma responsabilidade individual: a) os crimes contra a paz $[\ldots]$ b) os crimes de guerra [...] c) os crimes contra a humanidade [...]". 
Segundo Bazelaire e Cretin dois fatos históricos serviram de base às acusações, o chamado Massacre de Nanquim ${ }^{224} \mathrm{e}$ as experiências médicas feitas em prisioneiros chineses, russos e americanos, no qual pelo menos 9 mil pessoas morreram em decorrência de contaminações voluntárias.

Sua criação se deu em maio de 1946 e era composto por juízes provenientes de onze nações aliadas e, apesar de possuir quase metade de artigos do Acordo de Londres, sua substância e forma eram demasiado parecidas. Como exemplo dessa semelhança as penas seriam também definidas de acordo com critérios de justiça e razoabilidade, cabendo pena capital. Não obstante, em Tóquio os procuradores das potências aliadas eram apenas assistentes dos procuradores dos Estados Unidos, o que gerou críticas, já que esse país também fazia as vezes de acusador. (BAZELAIRE; CRETIN, 2004)

Mais recentemente, em maio de 1993 foi criado o Tribunal para a Antiga Iugoslávia (TPII) com sede em Haia e com objetivo de acusar pessoas responsáveis por graves violações das leis humanitárias internacionais cometidas no território da Ex-Iugoslávia como a perseguição étnica aos albaneses. (BAZELAIRE; CRETIN, 2004)

Em 1999, pela primeira vez, um Chefe de Estado que estava no poder era alvo de acusações, Slobodan Milosevic, suspeito de cometer 66 crimes como violações de leis e costumes de guerra, crimes contra a humanidade e de deliberar a morte de mais de 200 mil pessoas. (CALETTI, 2002)

O TPII conta com 14 juízes e uma corte de apelação e acusou aproximadamente 90 pessoas. (BAZELAIRE; CRETIN, 2004)

Mais um Tribunal $A d$ Hoc criado nos anos 90 do século passado é considerado de extrema importância na história do TPI, o Tribunal para Ruanda (TPIR), criado em setembro de 1998, com sede na Tanzânia, foi o primeiro a aplicar a Convenção de Genebra de 1948 sobre Genocídio. Isso porque o surgimento desse tribunal se deu em virtude do genocídio ocorrido entre abril e julho de 1994 e cujo número de mortos oscilaria entre 500 mil e um milhão de pessoas na Ruanda. Tal situação refere-se à crise de ódio tribal entre etnias hutu e tutsi em conflito desde tempos longínquos, que foi agravado desde a independência. (BAZELAIRE; CRETIN, 2004)

Assim, é importante explicitar as circunstancias que originaram o conflito. Em abril de 1994 o avião que transportava o Presidente da Ruanda foi abatido, tendo sido esse atentado tomado como pretexto para a guarda presidencial e os extremistas hutus instalarem barricadas nas ruas da capital e responsabilizassem os tutsis pelo atentado. (BAZELAIRE; CRETIN, 2004) Após esse fato, a situação recrudesceu até o ponto em que não havia mais segurança para os tutsis e para os hutus moderados, que eram mortos em suas residências e nas ruas e nos campos da Ruanda.

O TPIR possui duas câmaras e uma corte de apelação (que é a mesma do

224 Em dezembro de 1937 tropas japoneses entraram e saquearam a capital chinesa. Estima-se 300 mil mortes e 20 mil mulheres estupradas (BAZELAIRE; CRETIN, 2004, p. 29) 
TPII) e competência para julgar qualquer pessoa responsável por genocídio, crimes contra a humanidade e violações às Convenções de Genebra cometidas na Ruanda, tendo acusado 48 pessoas. (BAZELAIRE; CRETIN, 2004)

Pode-se dizer que este tribunal violou o princípio da individualização das penas haja vista não trazer penas específicas para cada delito (isso também ocorreu no tribunal para a Antiga Iugoslávia). Cabe ressaltar também que o TPIR não foi criado para julgar crimes de guerra, mesmo porque se tratava de uma guerra interna, mas para julgar violações ao Direito Internacional. (CALETTI, 2002)

Muito importante salientar que os avanços e experiências destes Tribunais permitiram que se alcançasse o sucesso das negociações que resultaram no Estatuto de Roma. Como acima demonstrado, cada um destes tribunais foi criado com objetivos peculiares e para casos específicos, o que resultou no questionamento de sua legalidade. Assim ficou claro para a sociedade internacional que a apuração de tais crimes internacionais, no caso de ocorrerem, ficariam à mercê de tribunais cujas atividades e legitimidades seriam postos à prova.

Tendo em vista todos esses problemas causados pela existência de Tribunais $A d H o c$ surgiu a necessidade de criação de um Tribunal Penal Internacional permanente que continuasse de maneira mais eficiente o trabalho dos tribunais ad hoc, ou seja, o TPI.

\section{O TPI}

Antes mesmo de o Tribunal Penal Internacional surgir, em 1937 a Sociedade das Nações elaborou uma convenção sobre Terrorismo, na qual estava previsto o estatuto de um tribunal criminal internacional permanente. Entretanto, apenas uma nação, a Índia, o ratificou e este tribunal nunca entrou em vigor.

O Tribunal Penal Internacional foi criado por uma convenção multilateral cujas atividades se encerraram em 17 de julho de 1998, data em que o Estatuto de Roma foi assinado por 120 votos a favor, 7 contra (China, EUA, Bahrein, Índia, Israel, Catar e Vietnã) e 21 abstenções. Todavia, o TPI somente existiria efetivamente quando conseguisse 60 ratificações, o que ocorreu em abril de 2002. (CALETTI, 2002)

Nas palavras de Jankov "o TPI é uma instituição internacional permanente estabelecida por um tratado, com jurisdição sobre as pessoas responsáveis pelos crimes de maior gravidade com alcance internacional". (JANKOV, 2009, p. 238)

De acordo com Kirsch, citado por Antonio Cassese, é importante ressaltar que o Estatuto de Roma não foi, em momento algum, imposto pelo Conselho de Segurança, ao contrario, foi muito discutido e negociado, o que acabou gerando inclusive tensão entre a jurisdição internacional e a soberania de cada estado. (KIRSCH apud CASSESE, 2004)

O Estatuto de Roma é um tratado internacional com texto normativo que 
regula o funcionamento da Corte, tipifica os crimes e estabelece um procedimento de julgamento criminal. Por muitos juristas é classificado como possuidor de uma jurisdição universal, mas de acordo com Jankov este princípio não foi reconhecido pelo Estatuto de Roma. Segundo o autor, o caráter multilateral que lhe é peculiar pode permitir a utilização do direito consuetudinário, que seria aplicável inclusive para aqueles Estados não signatários. (JANKOV, 2009)

Não obstante, o Estatuto de Roma possui força vinculante apenas entre os Estados- Partes, haja vista não ser um órgão supranacional, mas internacional. Não pode portanto, ser considerado como substituto da jurisdição penal nacional, mas apenas como órgão complementar, ou seja, como uma extensão da mencionada jurisdição. (JANKOV, 2009)

O Tribunal possui sede em Haia, na Holanda e é vinculado ao sistema das Nações Unidas, assim, os idiomas oficiais são os mesmos: mandarim, inglês, Frances, russo, árabe e espanhol. É composto por 18 juízes eleitos pela Assembléia dos Estados- Partes entre os candidatos com maior número de votos e maioria de 2/3 dos Estados-Partes votantes. O Tribunal possui ainda quatro órgãos principais, quais sejam a Presidência, as Câmaras (que se dividem em de julgamento e de recurso), a promotoria e a Secretaria.

O TPI pode ter algumas limitações, mas ainda assim é de suma importância para a comunidade internacional, haja vista se tratar de uma Corte Original destinada a julgar crimes que não se amoldam ao perfil dos crimes previstos nas legislações internas. Pode-se citar como uma limitação o fato da competência da Corte se restringir apenas a crimes cometidos depois da entrada em vigor do Estatuto, cabendo ressaltar, porém, que isso não impede o julgamento por outros órgãos jurisdicionais competentes, como órgãos $a d$ hoc, ou até mesmo tribunais nacionais sob o princípio da jurisdição universal. (JANKOV, 2009)

Por ser um tribunal permanente, exerce jurisdição sobre os nacionais dos Estados-Partes, ou seja, está aberto à participação de todos os Estados, diferentemente do que ocorria com os tribunais ad hoc. Isto explica o princípio da jurisdição universal supracitado. (SOUZA, 2005)

De acordo com o artigo 25 do Estatuto de Roma, o TPI possui competência para julgar e punir somente pessoas físicas que cometerem os crimes elencados no mencionado artigo $5^{\circ}$. (Princípio da responsabilidade penal individual)

Cabe destacar ainda o artigo 27 do referido Estatuto, no qual resta expresso que a competência do tribunal aplica-se de forma igual a todas as pessoas, sem distinção baseada em qualidade oficial. E, em momento algum se refere à uma redução de pena a qualidade da pessoa acusada.

Cumpre transcrever a visão de Fernanda Nepomuceno a respeito da competência da Corte:

O TPI deve exercer sua competência independentemente do lugar onde os 
crimes tenham sido perpetrados e estará capacitado a atuar, quando os Estados não possam ou não estejam dispostos a processar criminosos. (SOUZA, 2005, p. 93)

Igualmente, acerca da matéria de competência do TPI cabe trasladar trecho do artigo $5^{\circ}$ do Estatuto de Roma:

A competência da Corte restringir-se-á aos crimes mais graves, que afetam a comunidade internacional no seu conjunto [...]: crime de genocídio, crimes contra a humanidade, crimes de guerra e crime de agressão.

Assim, o TPI se limita a julgar os crimes mais graves que preocupam a comunidade internacional e o artigo 11 do Estatuto é claro ao dispor que o Tribunal só terá competência relativamente aos crimes cometidos após a entrada em vigor do Estatuto de Roma. Desta feita, o TPI não poderá ser acusado de aplicar critérios retroativos de justiça, como ocorreu com os tribunais de Nuremberg e Tóquio (Princípio da não-retroatividade) (SOUZA, 2005)

Uma regra de estrema importância para a presente pesquisa é a de que todos os Estados são obrigados a processar através de seus tribunais internos aqueles responsáveis por crimes de genocídio, de guerra e contra a humanidade. Se não o fizerem, em regra, deverão extraditar o responsável para um país que possa ou esteja disposto a fazê-lo. Cabe destacar o artigo 20 do Estatuto que trata da proibição do bis in idem, ou seja, ninguém pode ser julgado pelo TPI se já tiver sido condenado ou absolvido por este crime. (SOUZA, 2005)

Foi assim que, em dezembro de 1973, a Assembléia Geral da ONU adotou a Resolução 3.074 na qual se prevê que todos os estados deverão colaborar para processar responsáveis por tais crimes. Assim, como muito bem observou Fernanda Nepomuceno:

[...] os Estados que não sejam partes no estatuto estarão desobrigados de cooperar com o TPI. Contudo, se não processarem os responsáveis por crimes fundamentais em seu território ou jurisdição, não o extraditarem para outro Estado não o transladarem por solicitação do TPI, estarão descumprindo um dever internacional, reconhecido por todos os Estados. (SOUZA, 2005, p. 95)

Acerca dessa cooperação, cabe destacar que é matéria imprescindível para o funcionamento eficaz do TPI, seja através de convocação de testemunhas, ou por meio de provas documentais, detenção e transferência dos acusados. Os Estados -partes devem cooperar plenamente com o TPI na investigação e na persecução dos 
crimes que se encontram sob sua jurisdição. ${ }^{225}$

A maioria dos estados adotam dispositivos constitucionais que vedam a extradição de nacionais, portanto, o Estatuto de Roma em seu artigo 102 diferenciou o instituto da 'entrega' ao da extradição. Tais institutos são respectivamente a previsão de entrega um indivíduo ao TPI, ou o processo bilateral que ocorre entre dois Estados em que um deles, mediante uma requisição formal, envia ao outro um indivíduo que estaria sendo processado ou já tenha sido condenado por crime passível de extradição. (KRIEGER, 2004)

No artigo 75 do estatuto de Roma há previsão da reparação às vítimas através de restituição, compensação ou ainda reabilitação, sendo que também há previsão de um fundo de benefício das vítimas e de seus familiares.

Outro importante tópico acerca do TPI é a exclusão da responsabilidade criminal prevista no artigo 31 do Estatuto de Roma, que enumera circunstancias excludentes de responsabilidade, como por exemplo, doença mental, intoxicação involuntária, legítima defesa, dentre outras. (KRIEGER, 2004)

Desta forma, pode-se concluir que o TPI é um marco na proteção dos direitos humanos tendo em vista que sua finalidade é sanar eventuais falhas e insucessos dos tribunais nacionais, que muitas vezes acabam deixando muitos indivíduos impunes, principalmente quando se tratam de autoridades estatais.

\subsection{A SOBERANIA E A JURISDIÇÃo DO TPI}

O conceito clássico de soberania foi elaborado por Jean Bodin, concebida, portanto como: "[...] o poder supremo sobre os cidadãos e súditos, independente das leis positivas [...]" (SOARES, 1999, p. 21). Todavia, este conceito absoluto perdeu validade no século XVI quando o DIP se originava, mesmo que rudimentarmente, formando as relações jurídicas entre Estados soberanos.

A palavra soberania já existia na antiguidade e na idade média e, significava apenas uma posição daquele que era superior num sistema hierárquico.

O termo soberania aparece no final do século XVI, juntamente com o estado, para indicar, em toda sua plenitude, o poder estatal, sujeito único e exclusivo da política. (SOUZA, 2005, p. 122)

Kelsen demonstrou a incompatibilidade entre a noção tradicional de soberania com o DIP e o estabelecimento de uma ordem jurídica internacional e, assim, principalmente após a primeira Guerra Mundial, o conceito vem sendo reformulado através dos tratados internacionais. (SOARES, 1999)

Resta claro, portanto que o conceito de soberania passou por uma evolução desde sua concepção e hoje pode-se dizer que é afetado em dois sentidos: dentro do

225 Artigo 89 do Estatuto de Roma do Tribunal Penal Internacional. 
contexto de blocos econômicos e em relação às organizações internacionais. No que diz respeito a esse ultimo caso, que se refere ao TPI, por esse ser uma organização internacional, a soberania aplica-se por meio da delegação, que se manifesta através do princípio da complementaridade. (SOUZA, 2005)

Neste tópico do trabalho é importante lembrar que houve muita resistência para que o TPI fosse criado, e foi preciso muitos esforços para se conseguir estabelecer a Corte. Fato é que muitos Estados consideravam o Tribunal Penal Internacional um grande incômodo, seja por motivo do totalitarismo de um Estado ou porque a soberania era prioridade incondicional. (KIRSCH apud CASSESE, 2004)

Foi necessário, todavia, dar muitas garantias aos Estados para que o TPI fosse aceito. O princípio da complementaridade (que será tratado em capítulo específico) é um ótimo exemplo, pois, o TPI não poderá exercer sua competência enquanto o Estado não demonstrar sua incapacidade em abrir um inquérito ou instaurar processos. Vale ressaltar que esta é uma diferença essencial entre o TPI e os Tribunais Ad Hoc que não possuíam esse caráter complementar. (KIRSCH apud CASSESE, 2004)

Em suma, “[...] o Estatuto de Roma contém muitas disposições visando proteger a soberania dos Estados. Em consequência a corte dispõe de uma margem de manobra relativamente limitada [...]" (KIRSCH apud CASSESE, 2004, p.32)

Pode-se dizer, portanto que o Direito Internacional está voltado à proteção dos interesses estatais e da soberania, em um conjunto com garantias e valores universais. (SOUZA, 2005)

De acordo com Philippe Kirsch:

os Estados não queriam uma Corte que fosse criada pelo conselho de Segurança, para evitar uma justiça seletiva, em que membros permanentes do Conselho de Segurança controlariam a jurisdição penal internacional, estando eles próprios excluídos a priori de sua competência em razão de seu direito de veto em vigor no Conselho de Segurança. (KIRSCH apud CASSESE, 2004, p. 30)

E, conforme visto anteriormente, escolher a via do Conselho de Segurança e não optar pela via das negociações poderia então levar à criação de um Tribunal menos eficaz.

Grandes progressos foram feitos desde a entrada do TPI em vigor, inclusive com a participação de muitos dos países que haviam votado contra o Estatuto, que o subscreveram posteriormente. (KIRSCH apud CASSESE, 2004)

Por derradeiro, o Tribunal Penal Internacional pode então ser entendido como uma extensão da jurisdição penal nacional, já que "o TPI não infringe a soberania nacional nem desprestigia os sistemas jurídicos nacionais que desejam e podem cumprir suas obrigações internacionais". (JANKOV, 2009, p. 239) 
Passa-se então a classificação dos crimes que são julgados pelo TPI.

\subsection{Crime contra a humanidade}

Esta expressão compreende "quaisquer atrocidades e violações de direitos humanos perpetrados em larga escala para cuja punição é possível aplicar-se o princípio da jurisdição universal". (MAZZUOLI, 2007, p. 753)

A definição mais recente é a do estatuto do TPI, em seu artigo $7^{\circ}$ :

[...] entende-se por «crime contra a Humanidade» qualquer um dos atos seguintes, quando cometido no quadro de um ataque, generalizado ou sistemático, contra qualquer população civil, havendo conhecimento desse ataque:

a) Homicídio;

b) Extermínio;

c) Escravidão;

d) Deportação ou transferência à força de uma população;

e) Prisão ou outra forma de privação da liberdade física grave, em violação das normas fundamentais do direito internacional;

f) Tortura;

g) Violação, escravatura sexual, prostituição forçada, gravidez à força, esterilização à força ou qualquer outra forma de violência no campo sexual de gravidade comparável;

h) Perseguição de um grupo ou coletividade que possa ser identificado, por motivos políticos, raciais, nacionais, étnicos, culturais, religiosos ou de sexo, tal como definido no n. ${ }^{\circ} 3$, ou em função de outros critérios universalmente reconhecidos como inaceitáveis em direito internacional, relacionados com qualquer ato referido neste número ou com qualquer crime da competência do Tribunal;

i) Desaparecimento forçado de pessoas;

j) Crime de apartheid;

k) Outros atos desumanos de caráter semelhante que causem intencionalmente grande sofrimento, ferimentos graves ou afetem a saúde mental ou física.

Esse tipo de crime atenta contra bens jurídicos individuais e fundamentais, quais sejam a vida, integridade física, saúde, liberdade, etc. É portanto, uma ofensa a certos princípios do direito internacional e para a sua configuração não é necessário que tenha sido declarada a guerra. (SOUZA, 2005) 


\subsection{CRime De GUerRa}

Segundo Mazzuoli, este crime é também conhecido como "crimes contra as leis e os costumes aplicáveis em conflitos armados". Exemplos desse crime são as violações às Convenções de Genebra, como o homicídio doloso e a tortura. (MAZZUOLI, 2007, p. 754)

A competência deste crime é tratada no parágrafo primeiro do artigo $8^{\circ}$ do estatuto de Roma e diz que: "o tribunal terá competência para julgar os crimes de guerra, em particular quando cometidos como parte integrante de um plano ou uma política ou como parte de uma prática em larga escala desse tipo de crime."

Para o direito internacional consuetudinário, os crimes contra a humanidade são passíveis de ocorrer a qualquer momento, ou seja, mesmo em tempos de paz e essa é a diferença essencial entre estas duas categorias de crimes. (MAZZUOLI, 2007)

\subsection{Crime de Genocídio}

Este conceito foi uma das principais preocupações do período pós Segunda Guerra que acabou culminando na Resolução 260-A da Assembléia Geral das Nações Unidas em 1948, na qual ficou determinado que genocídio é um crime internacional e é a espécie mais grave de crime contra a humanidade. (MAZZUOLI, 2007)

$\mathrm{O}$ artigo $6^{\circ}$ do estatuto de Roma definiu Genocídio como:

[...] um dos atos enumerados a seguir, cometidos com a intenção de destruir, no todo ou em parte, um grupo nacional, étnico, racial ou religioso, tais como:

a) Homicídio de membros do grupo;

b) Ofensas graves à integridade física ou mental de membros do grupo;

c) Sujeição intencional do grupo a condições de vida pensadas para provocar a sua destruição física, total ou parcial;

d) Imposição de medidas destinadas a impedir nascimentos no seio do grupo;

e) Transferência, à força, de crianças do grupo para outro grupo.

Sobre esse conceito, não é preciso levar em consideração circunstancias exteriores de paz e de guerra ou a qualidade do autor, que pode ser um governante ou até mesmo um particular agindo por conta própria. (BAZELAIRE; CRETIN, 2004)

Neste quadrante, é necessário salientar um componente essencial do crime de genocídio, qual seja o elemento intencional de destruir um grupo tendo em vista sua nacionalidade, etnia, raça ou religião. $\mathrm{O}$ dolo, deve ser provado, e, sem ele o genocídio não pode ser configurado. (KRIEGER, 2004) 
Grandes polêmicas cercam este conceito, como por exemplo, se estupro pode ser considerado genocídio ou ainda qual o número de vítimas são necessárias para configurar o crime. Acerca desta última, o Tribunal para a Antiga Iugoslávia indicou que "a efetividade da destruição parcial ou total do grupo não é necessária [...], basta que um dos atos enumerados na definição seja perpetrado com a intenção específica".

O que realmente importa, portanto, é a intenção e o ato de destruição, sem aproximação quantitativa. (BAZELAIRE; CRETIN, 2004)

\subsection{CRIMe de AGRessão}

Segundo previsão do artigo $5^{\circ}$ do Estatuto de Roma

O Tribunal poderá exercer a sua competência em relação ao crime de agressão desde que, nos termos dos artigos $121 .^{\circ}$ e $123 .^{\circ}$, seja aprovada uma disposição em que se defina o crime e se enunciem as condições em que o Tribunal terá competência relativamente a este crime. Tal disposição deve ser compatível com as disposições pertinentes da Carta das Nações Unidas.

Isto significa que a competência do TPI para o crime de agressão somente poderá ser exercida depois que um dispositivo definir seu conceito. De acordo com Krieger, a definição desse crime não obteve consenso durante a conferencia de Roma porque haviam posições diferentes, mas fato é que, ao mesmo tempo, todos concordaram ser necessária sua inclusão no estatuto. (KRIEGER, 2004)

Não obstante, esse crime apareceu pela primeira vez com o nome de 'crime contra a paz' elencado no artigo $6^{\circ}$ do Tribunal Militar de Nuremberg e foi definido como

a direção, preparação, o desencadeamento ou a continuidade de uma guerra de agressão, ou uma guerra violando tratados, garantia ou acordos internacionais, ou a participação em um plano orquestrado ou em um complô para o cumprimento de qualquer um dos atos anteriores. (BAZELAIRE; CRETIN, 2004, p. 81)

Em termos bem semelhantes, o crime de agressão pode ser encontrado no artigo $5^{\circ}$ do Tribunal para Tóquio, mas ainda assim este conceito possui certa dificuldade em ser explicado e as únicas referencias que se têm são as jurisprudências produzidas pelo Tribunal de Nuremberg. (BAZELAIRE; CRETIN, 2004)

\subsection{Princípios aplicados ao TPI}

Um dos principais princípios é o da complementaridade que está inserido 
no preâmbulo e no artigo $1^{\circ}$ do Estatuto de Roma o qual diz que o TPI possui caráter subsidiário às jurisdições nacionais.

Há, porém, exceções, como quando há incapacidade dos Estados em julgar ou no caso de não estarem em condições ou com disposição para fazê-lo. Outro exemplo ocorre na situação em que o processo e o julgamento não são conduzidos de forma imparcial, com claras tendências a serem mera formalidade não eficaz para apurar e punir o crime em questão. (SOUZA, 2005)

No entanto, ao chamar para si a competência, resta claro que a justiça local não funcionou e, para tanto, o TPI deverá justificar-se dizendo que esta é a razão para que possa julgar o caso. (SOUZA, 2005)

Cabe ainda ressaltar que este princípio representa também um esforço com vistas a preservar a soberania dos Estados bem como outras garantias estatais. (KIRSCH apud CASSESE, 2004)

O princípio da responsabilidade penal internacional dos indivíduos é um dos mais importantes, haja vista sua consagração ser uma conquista da Humanidade.

O Estatuto de Roma seguiu aquilo que dizia o Tribunal de Nuremberg com relação à responsabilidade internacional dos indivíduos:

Crimes contra o direito internacional são cometidos por indivíduos, não por entidades abstratas e os preceitos de direito internacional fazem-se efetivos apenas com a condenação dos indivíduos que cometeram esses crimes. (MAZZUOLI, 2007, p. 758)

Este princípio encontra-se elencado no artigo 25 do Estatuto de Roma, o qual determina que se concentra na competência exclusiva da corte sobre pessoas físicas ou naturais. É importante ressaltar que isso não afeta em nada a responsabilidade do Estado conforme o Direito Internacional, se este for o caso. (SOUZA, 2005)

Não obstante, o princípio em questão delimita alguns preceitos, como o de que menores de 18 anos são inimputáveis e de que uma pessoa pode ser punida pela Corte se agir com intenção e conhecimento dos elementos materiais do crime, ou seja, em regra, os crimes são punidos a título de dolo. (SOUZA, 2005)

O princípio da responsabilidade penal internacional dos indivíduos estabelece também o critério da improcedência do cargo oficial, em virtude do qual o Estatuto deve ser aplicado igualmente a todos, sem distinções, o que afasta as imunidades dos Chefes de Estado ou autoridades que exerçam cargos oficiais.

Conforme Fernanda Nepomuceno:

O TPI deverá, então, processar qualquer pessoa responsável pela prática de crimes fundamentais, independentemente do lugar em que foram cometidos e do cargo ou posição que ocupe, seja soldado raso, comandante, ministro da defesa, primeiro-ministro, presidente ou rei. (SOUZA, 2005, 


\section{p. 105)}

Ante o exposto, resta claro que o regime de responsabilidade definido pelo Estatuto de Roma é universal, individual e pleno, pois permite a intervenção da Corte para julgar as pessoas que os tribunais nacionais não puderam fazê-lo. (SOUZA, 2005)

Outro princípio que encontra guarida no próprio Estatuto de Roma em seu artigo 22 é o da legalidade internacional:

1 - Nenhuma pessoa será considerada criminalmente responsável, nos termos do presente Estatuto, a menos que a sua conduta constitua, no momento em que tiver lugar, um crime da competência do Tribunal.

2 - A previsão de um crime será estabelecida de forma precisa e não será permitido o recurso à analogia. Em caso de ambiguidade, será interpretada a favor da pessoa objeto de inquérito, acusada ou condenada.

3 - O disposto no presente artigo em nada afetará a tipificação de uma conduta como crime nos termos do direito internacional, independentemente do presente Estatuto.

Desta feita, de acordo com este princípio, alguém só pode ser punido se antes de praticar o ato já exista lei que o considere crime (Nullum crimen sine lege), impedindo, portanto, que a Corte criminalize condutas tendo como base o direito costumeiro. (SOUZA, 2005)

Fernanda Nepomuceno cita ainda três princípios derivados deste, quais sejam o da legalidade das penas (nulla poena sine lege ${ }^{226}$ ), o da escrita e o da não-retroatividade ${ }^{227}$, tendo sido esse último foi duramente criticado em vista do grande medo no que concerne à possibilidade de impunidade em relação às condutas pretéritas. (SOUZA, 2005; AMBOS; CHOUKR, 2000)

Outro princípio importante é o ne bis in idem ${ }^{228}$, que, de acordo com Ambos e Hassan, o indivíduo poderá invocá-lo sempre que já tiver sido condenado ou absolvido pela mesma conduta. (AMBOS; CHOUKR, 2000)

Excepcionalmente, entretanto, o agente pode ser julgado diante do Tribunal Penal Internacional, se a Corte nacional tiver afastado sua responsabilidade criminal ou caso o julgamento não tenha acontecido com independência e imparcialidade. (AMBOS; CHOUKR, 2000, p. 28)

Mais um princípio é o do juiz natural, pois o juiz deve ser estabelecido

226 Artigo 23 do Estatuto de Roma do Tribunal Penal Internacional.

227 Artigo 24 do Estatuto de Roma do Tribunal Penal Internacional.

228 Artigo 20 do Estatuto de Roma do Tribunal Penal Internacional. 
previamente, ou seja, antes dos crimes serem cometidos, sendo os juízos de exceção são terminantemente proibidos, evitando assim a parcialidade. (MAZZUOLI, 2007)

Relevante destacar que o princípio da legalidade é um princípio básico de justiça e pode ser tido como um dos raros princípios que não apresenta derrogações. Observa-se que devido o grande detalhamento das previsões do Estatuto de Roma atesta uma real obsessão para com este preceito. (AMBOS; CHOUKR, 2000)

O Princípio da não-discriminação não deve ser esquecido, e, de acordo com Brownlie, se aplica com base em raça e sexo. O referido doutrinador diz ainda que a discriminação ilegal deve ser diferenciada das razoáveis medidas de diferenciação. (BROWNLIE, 2003)

Há ainda o Princípio da igualdade, que também segundo Brownlie não deve ser baseado em um conceito mecânico, pois a distinção deve ter uma justificação objetiva, ou seja, ao estabelecer um tratamento diferente, esse deve ser proporcional à justificativa para a diferenciação. (BROWNLIE, 2003)

Por fim, cumpre destacar o princípio da jurisdição universal do TPI, segundo o qual a maioria dos doutrinadores entende que o tribunal possui sua própria jurisdição prescritiva, a qual the permite adotar o princípio em comento. Todavia, a minoria, como Fernanda Jankov, afasta a noção da jurisdição universal do TPI, haja vista entendimento de que os demais tribunais internacionais recebem dos Estados, por meio de delegação, a jurisdição. (JANKOV, 2009)

Ainda de acordo com Jankov, o Estatuto de Roma possui um caráter multilateral e, assim, quanto mais ratificações, mais fácil se torna a aceitação da idéia de uma jurisdição universal. "Podendo-se falar na constituição do direito consuetudinário aplicável mesmo aos estados que não ratificaram o estatuto". (JANKOV, 2009, p.238)

\section{DARFUR}

\section{1 História do SUdão}

Entre 1820 e 1822 o país foi conquistado pelos egípcios, que reprimiram cruelmente a revolta dos sudaneses, foi também quando a cidade de Cartum, que era uma base militar, foi transformada em capital administrativa.

A ocupação egípcia trouxe modernizações ao Sudão, como a criação de serviços de correios e telégrafos, além do desenvolvimento econômico, mas, em contrapartida, a captura de escravos era usada como recrutamento para o exército egípcio. A fase final da mencionada ocupação se concretizou com a conquista de DARFUR ${ }^{229}$.

Em 1881, o sudanês Mohamed Ahmed proclamou-se Madhí, Enviado de

229 Região no extremo oeste do Sudão, na fronteira com a Líbia, o Chade e República Centro-Africana. 
Alá para restaurar o Islam, e começou a se opor ao domínio egípcio liderando assim uma revolta. Aproveitando a presença britânica no país, se juntou a rebeldes sudaneses e foi à Cartum para reconquistar seu país, o que culminou na morte do general inglês George Gordon em 1885 e na expulsão das guarnições egípcias.

Dezessete anos mais tarde, um grupo anglo-egípcio liderou a reconquista do país, e, no mesmo ano, os seguidores de Madhí foram derrotados e a área entre o rio Nilo e a capital Cartum acabou ocupada.

Ao mesmo tempo os Franceses e os Britânicos chegaram a um acordo, no qual a França reconheceu a hegemonia inglesa sobre o Nilo e assim partilharam as áreas de interesse africanas. No entanto, o Egito continuou a reivindicar o Sudão, mas em 1924 o país começou com um movimento nacionalista aspirando à independência. Houve, portanto, uma divisão dos sudaneses e, enquanto alguns pleiteavam a independência política completa, outros eram favoráveis à integração ao Egito.

Em 1953, Grã-Bretanha e Egito firmaram um acordo, no qual se comprometeram a conceder a independência ao Sudão dentro de três anos. Desta feita, no primeiro dia do ano 1956 a independência foi proclamada.

O primeiro ministro sudanês foi eleito pela Assembléia e tomou posse em 1958, contudo, no mesmo ano, o general Abbud tomou o poder com um golpe militar, consumando no restabelecimento das relações com o Egito e no inicio do auxilio econômico por parte dos EUA e antiga União Soviética, URSS.

O general foi obrigado a abandonar o poder em 1964 com a revolução popular, na qual Madhí retomou o poder e, logo depois, em 1969, Madhí foi destituído através de um novo golpe militar. O novo chefe de Estado, Gaafar al- Nimeiry, conseguiu então pacificar o sul em 1972, depois de 17 anos de sedição separatista, pondo fim temporariamente a uma longa guerra civil.

Porém, a paz alcançada foi prejudicada em razão de uma segunda guerra civil que eclodiu em 1983.

Até então, o país se encontrava nem uma situação estável e mais ou menos confortável quando foi assolado pela seca e pela chegada de inúmeros refugiados vindos principalmente da Etiópia. Nimeiry tentou consolidar sua base de apoio entre os fundamentalistas islâmicos, introduzindo a Sharia ${ }^{230}$, o que desencadeou em uma guerrilha separatista do sul do país, resultando em 350 mil refugiados e mais uma guerra civil.

Em 1985, o exército conseguiu então derrubar Nimeiry, com apoio de movimentos populares e greves, mas a guerra civil continuou: o Exercito de Libertação do Povo Sudanês (ELPS) militarizando o sul do país enquanto a Frente Islâmica Nacional (FIN) fortalecia sua presença no norte.

As primeiras eleições parlamentares democráticas foram realizadas no ano seguinte. No poder, ficou uma coligação dos partidos do norte que, inclusive, tentou

230 Lei islâmica que tem o Corão como fonte. Dentre outras coisas, determina a proibição de bebidas alcoólicas e punições por enforcamento e mutilação. 
negociar sem sucesso com o sul, até que em junho de 1989, o general de brigada Omar al-Bashir depôs o primeiro ministro, declarou estado de emergência e nomeou um Conselho de Estado. Esse novo governo baniu os partidos políticos, se deixou influenciar pelo fundamentalismo islâmico e nada fez para apaziguar os rebeldes do sul do Sudão.

\subsection{O CONFLITO EM DARFUR}

O conflito teve início no ano de 2003 quando grupos rebeldes da região de DARFUR atacaram postos do governo sudanês alegando anos de descaso e abandono por parte do governo de Cartum.

Em resposta, os Janjawid atacaram os povos não árabes da região de DARFUR, com ajuda do governo do Sudão que fornece armas de fogo para os combates e ainda auxiliam e participam em conjunto destes ataques.

Em 2004 o Conselho de Segurança da ONU aprovou a resolução 1564 que estabeleceu uma comissão de inquérito em DARFUR para avaliar o conflito, chegando à conclusão de que ainda não tinham condições de classificar o conflito como genocídio, haja vista a falta do elemento principal, qual seja, a intenção.

Houve uma intensificação do confronto em 2006 e o CS acabou aprovando a resolução 1706 prevendo o envio de uma força de manutenção da paz da ONU, todavia, o Sudão se opôs à resolução e lançou mais ofensivas militares na região.

Em 2008 procuradores do TPI processaram o Presidente do Sudão, Omar al-Bashir por crimes de guerra e contra a humanidade e já no ano seguinte, o Tribunal emitiu seu mandado de prisão. (GLOBO.COM, 2009)

Em julho de 2011, a partir de um acordo de paz de 2005 que encerrou a guerra civil, o Sudão do Sul foi reconhecido como Estado independente, mas o novo país e o Sudão estão em desacordo sobre a marcação da fronteira já que os sul-sudaneses ficaram com $75 \%$ das reservas petrolíferas do antigo Sudão. Os oleodutos e a saída para o Mar Vermelho ficaram com os sudaneses do Norte. O conflito quase parou toda a produção de petróleo, que é essencial para ambas as economias. (GLOBO.COM, 2012)

Em maio, o Sudão do Sul retirou as tropas de ambas as cidades, após intensos combates. A manobra de evasão militar, no entanto, serve mais para evitar possíveis sanções internacionais do que para selar a paz. Os dois países apoiam milícias armadas que saqueiam, estupram e matam por onde passam. "Não façam prisioneiros, não temos comida para eles", disse o chefe de um desses bandos, em uma reportagem da televisão local. Nesses conflitos, entidades de direitos humanos estimam em 10 mil o número de mortos só depois da independência. E cerca de 300 mil pessoas fugiram para as montanhas, levando o que puderam, e hoje vivem em cavernas para 
fugir da violência. (UOL, 2012)

Em 2012 a situação não melhorou; o país sofre um grande trauma com a separação do Sul, rico em petróleo e que não sabe como gerir tal riqueza, acabam então enfrentando enorme inflação e crise económica profunda.

A situação é tão extrema, inclusive por causa da Sharia, que uma mulher grávida de 20 anos, foi condenada a morte por lapidação, pela acusação de adultério. O julgamento foi realizado em árabe, língua que ela não entende. (POR DARFUR, 2012) Este é um simples exemplo de tratamentos desumanos que vem ocorrendo na região desde 2003, onde ninguém é punido.

\section{ConClusão}

Em consonância com o Estatuto de Roma e seu artigo $4^{\circ}$, que dispõe acerca da possibilidade de julgar ou não um cidadão de um país que não o tenha assinado, a priori, não haveria de se falar em punição ou julgamento destes criminosos do Sudão.

Todavia, há possibilidade de que o TPI possa julga-los através de um acordo especial, exercendo seus poderes e funções, nos termos do presente Estatuto, no território de qualquer Estado Parte ou no território de qualquer outro Estado.

Em qualquer caso, deve-se basear em alguns princípios norteadores do TPI, que possuem tamanha importância para o Direito Internacional que devem ser respeitados mesmo em relação à soberania dos Estados; este é o caso dos direitos humanos. Conforme já foi discutido, normas de direitos humanos não dependem de qualquer condição para serem colocadas em prática, bastando assim a qualidade de ser humana para a pessoa poder fazer reivindicações.

Além disso, para que haja um julgamento justo pelo TPI, é necessário o cumprimento do princípio da complementaridade, segundo o qual a Corte possui caráter subsidiário às jurisdições nacionais. Cumpre ressaltar as exceções, como quando há incapacidade dos Estados em julgar ou eles não estejam em condições ou com disposição para fazê-lo, sendo este último o caso aplicável ao Sudão.

Ainda de acordo com os princípios norteadores do TPI, não restam dúvidas de que os cidadãos do Sudão que estão cometendo os crimes previstos no Estatuto de Roma devem ser julgados pelo Tribunal Penal Internacional. Em primeiro lugar, é possível sustentar tal entendimento porque o Tribunal, de acordo com o princípio da responsabilidade penal internacional dos indivíduos, pode julgá-los e, em segundo, porque tais crimes já foram tipificados antes mesmo da época dos atos.

Insta salientar o preâmbulo do Estatuto de Roma no que dispõe acerca da abstenção que devem se submeter os Estados ao deixar de recorrer à ameaça, de atuar por qualquer forma incompatível com os objetivos das Nações Unidas, não fazendo uso da força contra a integridade territorial ou contra a independência política de qualquer Estado. 
Desta feita, para efeitos dessa pesquisa, não restam dúvidas de que se o cidadão de um país comete crimes já tipificados em lei, que atente contra os direitos humanos ou contra princípios como da igualdade, da não discriminação, da dignidade da pessoa humana, dentre outros, pode e deve ser julgado pelo TPI, haja vista serem também os indivíduos sujeitos do DIP, o que acarreta na possibilidade de serem penal e internacionalmente responsabilizados.

\section{REFÊRENCIAS}

ALLAND, Denis. Droit international public. Paris: Puf, 2000.

AMBOS, Kai; CHOUKR, Fauzi Hassan. Tribunal Penal Internacional. São Paulo: Revista dos Tribunais, 2000.

BAZELAIRE, Jean-Paul; CRETIN, Thierry. A Justiça Penal Internacional. São Paulo: Manole, 2004.

BONAVIDES, Paulo. Curso de direito constitucional. São Paulo : Malheiros, 2003.

BRICHAMBAUT, Marc Perrin de; DOBELLE, Jean-François ; Haussy, Marie-Reine d'. Leçons de doit international public. Paris : Dalloz, 2002.

BROWNLIE, Ian. Principles of Public International Law. New York: Oxford, Ed. 6, 2003.

CALETTI, Cristina. Os precedentes do Tribunal Penal internacional, seu estatuto e sua relação com a legislação brasileira. UOL. Outubro de 2002. Disponível em: http://jus2.uol.com.br/doutrina/texto.asp?id=3986. Acessado em: 24.09.2010.

CASSESE, Antonio. International Law. New York: Oxford, Ed. 2, 2005.

ENCICLOPÉDIA Britânica do Brasil Publicações LTDA. São Paulo: 1991. p. 403407.CASSESE, Antonio; DELMAS-MARTY, Mireille. Crimes Internacionais e Jurisdições Internacionais. São Paulo: Manole, 2004.

ENCICLOPÉDIA Mirador Internacional. São Paulo: 1992. p. 10627-10630.

GLOBO. COM. Saiba mais sobre Omar al-Bashir, o presidente do Sudão. Disponível em: http://g1.globo.com/Noticias/Mundo/0,,MUL1027209-5602,00-SAI$\mathrm{BA}+\mathrm{MAIS}+\mathrm{SOBRE}+\mathrm{OMAR}+\mathrm{ALBASHIR}+\mathrm{O}+\mathrm{PRESIDENTE}+\mathrm{DO}+\mathrm{SUDAO}$. html. Acessado em: 30.06.2012.

GLOBO.COM. Recém-criado, Sudão do Sul diz buscar paz para ter desenvolvimento. Disponível em: http:/g1.globo.com/natureza/rio20/noticia/2012/06/recemcriado-sudao-do-sul-diz-buscar-paz-para-ter-desenvolvimento.html. Acesso em: 30 jun 2012

JANKOV, Fernanda Florentino Fernadez. Direito Internacional penal. São Paulo: 
Saraiva, 2009.

KRIEGER, César Amorim. Direito internacional Humanitário. Curitiba: Juruá, 2004.

MAZZUOLI, Valério de Oliveira. Curso de Direito Internacional Público. São Paulo: Revista dos Tribunais, 2007.

MELLO, Celso D. de Albuquerque. Curso de Direito Internacional Público. Rio de Janeiro: Renovar, 2004.

POR DARFUR. A Shária é quem mais ordena no Sudão de Al-Bashir. Disponível em: http://www.pordarfur.org/pt/noticias/detail/id/1853. Acessado em: 30.06.2012.

REZEK, Francisco. Direito Internacional Público. São Paulo: Saraiva, ed. 11, 2008.

ROMA, Estatuto do Tribunal penal Internacional (1998). Legislação de direito internacional. Organizada por Aziz Tuffi Saliba. São Paulo: Rideel, ed. 2, 2007.

SOARES, Mario Lucio Quintão. Mercosul Direitos Humanos, Globalização e Soberania. Belo Horizonte: Del Rey, ed. 2, 1999.

SOUZA, Fernanda Nepomuceno. Tribunais de Guerra. Belo Horizonte: Del Rey, 2005.

UNIDAS, Carta das Nações (1945). Legislação de Direito Internacional. Organizada por Aziz Tuffi Saliba. São Paulo: Rideel, ed. 2, 2007.

UOL. Sudão do Sul ficou independente há um ano, mas não há paz. Disponível em: http://noticias.uol.com.br/internacional/ultimas-noticias/2012/06/04/sudao-do-sulficou-independente-ha-um-ano-mas-nao-ha-paz.htm Acessado em: 30.06.2012 